\title{
Pengaruh Aplikasi Pupuk Organik Dan Pupuk Hayati Serta Reduksi Pupuk NPK terhadap Ketersediaan Hara dan Populasi Mikroba Tanah Pada Tanaman Padi Sawah Musim Tanam Kedua di Karawang, Jawa Barat
}

\section{The Effect of Application Organic Fertilizer and Biofertilizer with Compound Fertilizer (NPK) Reduction on the Availability of Nutrient and Soil Microbe Population of Paddy at Second Cultivate Season in Karawang, West Java}

\author{
Shoni Riyanti, Heni Purnamawati* dan Sugiyanta \\ Departemen Agronomi dan Hortikultura, Fakultas Pertanian, Institut Pertanian Bogor \\ (Bogor Agricultural University), J1. Meranti, Kampus IPB Darmaga, Bogor 16680, Indonesia \\ Telp.\&Faks.62-251-8629353 e-mail agronipb@indo.net.id \\ *Penulis untuk korespondensi: heni_purnama@yahoo.com
}

Disetujui 14 November 2015 /Published online 12 Desember 2015

\begin{abstract}
This research was conducted in Karawang, West Java on October 2010 to April 2011. The purpose of this research was to find out the effect of application of organic fertilizer and biofertilizer with compound fertilizer (NPK) reduction on the availability of nutrient and soil microbe population in paddy field at second cultivating season. The experiment used Complete Randomized Block Design consisted of 13 treatments. Those were $P 1=$ straw +0.5 dose NPK, $P 2=$ straw +0.5 dose NPK + Granule Organic Fertilizer $(G O F)+$ Liquid Organic Fertilizer $(L O F), P 3=$ straw +0.5 dose NPK + GOF, P4= straw + 0.5 dose NPK +GOF + biofertilizer 1, P5= straw + 0.75 dose NPK + biofertilizer 2, P6=sStraw + 0.5 dose $N P K+$ dung, $P 7=$ straw +0.5 dose $N P K+$ biofertilizer $1, P 8=$ straw +0.5 dose $N P K+$ biofertilizer $2, P 9=$ straw +1 dose NPK, P10= without straw +1 dose NPK, P11 = straw +0.5 dose NPK + biofertilizer 3 , $P 12=$ without straw +0.5 dose NPK + biofertilizer 3 , dan P13= without fertilizer. The result showed that the application of biofertilizer (bio 1, 2, or 3) can increased of nutrient availability and soil microbe population. The application influenced the number of tillering on the 7th WAP and leaf color at 3rd and 7th WAP. The grain yield of Straw +0.5 dose NPK + biofertilizer 2 not significant different with 1 dose NPK treatment.
\end{abstract}

Keywords: liquid organic fertilizer, straw, tillering

ABSTRAK

Penelitian dilakukan di Karawang, Jawa Barat pada bulan Oktober 2010 sampai April 2011. Tujuan penelitian adalah mengetahui pengaruh aplikasi pembenaman jerami dan pupuk hayati serta pupuk organik dalam mengurangi penggunaan pupuk NPK pada musim tanam kedua. Percobaan menggunakan Rancangan Kelompok Lengkap Teracak yang terdiri atas 13 perlakuan. Perlakuan tersebut adalah $P 1=$ jerami +0.5 dosis NPK, $P 2=$ jerami +0.5 dosis NPK + pupuk organik granul $(P O G)+$ pupuk organik cair $(P O C), P 3=$ jerami +0.5 dosis NPK $+P O G, P 4=$ jerami +0.5 dosis $N P K+P O G+$ pupuk hayati $1, P 5=$ jerami +0.75 dosis NPK + pupuk hayati $2, P 6=$ jerami +0.5 dosis $N P K+$ pukan, $P 7=$ jerami +0.5 dosis NPK + pupuk hayati $1, P 8=$ jerami +0.5 dosis $N P K+$ pupuk hayati $2, P 9=$ jerami +1 dosis $N P K, P 10=$ tanpa jerami + 1 dosis NPK, P11 = jerami +0.5 dosis NPK + pupuk hayati 3, P12 = tanpa jerami +0.5 dosis NPK + pupuk hayati 3, dan P13 = tanpa pupuk. Hasil penelitian menunjukkan bahwa penerapan pupuk hayati (bio 1, 2, atau 3) dapat meningkatkan ketersediaan hara dan populasi mikroba tanah. Aplikasi ini dipengaruhi jumlah pembentukan batang pada 7 MST dan daun berwarna pada 3 dan $7 M S T$. Jerami +0.5 dosis NPK + pupuk hayati 2 tidak berbeda signifikan dengan perlakuan 1 dosis NPK.

Kata kunci: jerami, pembentukan batang, pupuk cair organik 


\section{PENDAHULUAN}

Padi merupakan komoditas tanaman pangan utama Indonesia, namun laju peningkatan produktivitas padi mengalami pendataran. Salah satu penyebabnya adalah penggunaan pupuk anorganik dan pestisida yang berlebihan. Hal ini mengakibatkan hilangnya kemampuan mikroorganisme tanah yang membantu menyuburkan tanah (Dwiyanto, 2008). Penggunaan pupuk anorganik yang berlebihan dan terus menerus akan merusak sifat fisik, kimia, dan biologi tanah sehingga kesuburan tanah akan semakin menurun (Havlin et al., 2005).

Penggunaan pupuk organik dapat mengembalikan kesuburan tanah. Pupuk organik berfungsi menyediakan bahan organik bagi tanah. Pupuk organik mencakup pupuk kandang, kompos, pupuk hijau, sisa panen (jerami, brangkasan, tongkol jagung), limbah ternak, limbah industri, dan pupuk hayati. Bagi tanaman padi, jerami merupakan bahan organik yang paling potensial ketersediaannya. Jerami padi mengandung $0.6 \% \mathrm{~N}, 0.1 \% \mathrm{P}, 0.1 \% \mathrm{~S}, 1 \% \mathrm{~K}, 5 \%$ $\mathrm{Si}$ dan 40\% C (Cho and Kobata, 2002). Penggunaan jerami dapat menyediakan dan mengatur imobilisasi serta mineralisasi nitrogen di tanah.

Pupuk hayati merupakan pupuk yang berbahan aktif organisme hidup (mikroba) yang berfungsi untuk menambah hara tertentu atau memfasilitasi tersedianya hara dalam tanah bagi tanaman (Simanungkalit dan Suriadikarta, 2006). Widya (2006) menyatakan bahwa pupuk hayati bermanfaat untuk mengurai residu kimia, mensuplai sebagian $\mathrm{N}$ bagi tanaman, melarutkan senyawa fosfat. Pemanfaatan mikroorganisme dalam pupuk hayati juga dapat meningkatkan produksi tanaman dan kualitas lingkungan serta merupakan salah satu usaha untuk mengembalikan lingkungan yang rusak (Wolf and Wagner, 2005).

Kandungan mikroba dalam pupuk hayati mampu meningkatkan pertumbuhan dan produksi tanaman, tetapi perlu dipadu dengan hara lain (Hamim et al., 2007). Menurut Eagle (2000), penggunaan bahan organik jerami dapat meningkatkan efisiensi pemupukan. Oleh sebab itu, perlu diamati pengaruh penambahan jerami dan pupuk hayati serta reduksi pupuk anorganik terhadap ketersediaan hara dan mikroba dalam tanah agar penggunaan pupuk dapat lebih efisien dan efektif.

Penelitian ini bertujuan untuk mengetahui pengaruh aplikasi pembenaman jerami dan pupuk hayati serta pupuk organik dalam mengurangi penggunaan pupuk NPK pada musim tanam kedua terhadap ketersediaan hara dan mikroba dalam tanah pada tanaman padi sawah di Karawang.

\section{BAHAN DAN METODE}

Penelitian ini dilaksanakan pada bulan Oktober 2010 - April 2011 di Cibungur, Desa Karawang Wetan, Kecamatan Karawang Timur, Kabupaten Karawang. Analisis tanah dilakukan di Laboratorium SEAMEO Biotrop, sedangkan analisis mikroba di Laboratorium BB Biogen, Bogor.

Bahan yang digunakan dalam penelitian ini adalah benih padi varietas Ciherang, jerami, pupuk NPK (30-6-8), pupuk kandang, pupuk organik granul (POG), pupuk organik cair (POC) dan pupuk hayati $(\mathrm{PH})$ serta bahan-bahan kimia untuk analisis tanah dan mikroba. Alat yang digunakan adalah peralatan budi daya dan laboratorium untuk analisis.

Rancangan percobaan yang digunakan dalam penelitian ini adalah Rancangan Kelompok Lengkap Teracak (RKLT) yang terdiri atas 13 perlakuan dengan 3 kali ulangan. Setiap satuan percobaan berukuran $10 \mathrm{~m}$ x $20 \mathrm{~m}$. Perlakuan yang dilakukan adalah sebagai berikut:

P1 : Jerami + 0.5 Dosis NPK

$\mathrm{P} 2$ : Jerami + 0.5 Dosis NPK $+\mathrm{POG}+\mathrm{POC}$

$\mathrm{P} 3$ : Jerami +0.5 Dosis NPK + POG

$\mathrm{P} 4$ : Jerami +0.5 Dosis NPK $+\mathrm{POG}+\mathrm{PH} 1$

$\mathrm{P} 5$ : Jerami + 0.75 Dosis NPK + PH 2

P6 : Jerami + 0.5 Dosis NPK + pukan

P7 : Jerami + 0.5 Dosis NPK + PH 1

P8 : Jerami + 0,5 Dosis NPK + PH 2

P9 : Jerami + 1 Dosis NPK

P10: Tanpa Jerami + 1 Dosis NPK

P11: Jerami + 0.5 Dosis NPK + PH 3

P12: Tanpa Jerami + 0.5 Dosis NPK + PH 3

P13 : Tanpa pupuk

Penelitian diawali dengan menganalisis sampel tanah yang diteliti di Laboratorium SEAMEO BIOTROP, Bogor (diperoleh dari analisis pada musim tanam sebelumnya). Analisis tanah juga dilakukan pada akhir penelitian pada masing-masing perlakuan.

Pengolahan tanah disertai aplikasi jerami dan pupuk kandang (disesuaikan perlakuan). Jerami padi hasil panen (5 ton basah ha ${ }^{-1}$ ) ditaburkan diatas permukaan tanah sebelum pengolahan tanah sehingga dapat terbenam pada saat pengolahan tanah pertama.

Benih padi yang digunakan adalah varietas Ciherang $\left(20 \mathrm{~kg} \mathrm{ha}^{-1}\right)$. Benih disemai pada tampi semai dan petak semai di sawah yang telah disiapkan. Bibit dipindah tanam pada umur 
14 hari dengan 1 bibit per lubang tanam. Jarak tanam yang digunakan adalah ukuran $25 \mathrm{~cm} \times 15$ $\mathrm{cm}$ dan $40 \mathrm{~cm}$ antar kelompok barisan. Penyulaman dilakukan pada 1-2 minggu setelah tanam (MST) dengan bibit yang umurnya sama.

Pemupukan dilakukan pada satu minggu sebelum tanam berupa Pupuk Organik Granul $\left(200 \mathrm{~kg} \mathrm{ha}^{-1}\right)$, PH $1\left(1 \mathrm{~L} \mathrm{ha}^{-1}\right)$, dan PH $2\left(2 \mathrm{~L} \mathrm{ha}^{-1}\right)$ serta PH 3 (200 kg ha $\left.{ }^{-1}\right)$, selain itu pupuk kandang ditaburkan sesuai petak perlakuan $\left(2\right.$ ton $\left.\mathrm{ha}^{-1}\right)$. Selanjutnya dilakukan pemupukan NPK $(400 \mathrm{~kg}$ $\left.\mathrm{ha}^{-1}\right)$ dan POC $\left(2 \mathrm{~L} \mathrm{ha}^{-1}\right)$ pada $1 \mathrm{MST}$. Pemupukan Pupuk Organik Cair dilakukan pada 1, 3, 5, dan 7 MST. Pemupukan PH 1 dan PH 2 juga dilakukan pada 2, 4, dan 6 MST. Pengendalian gulma dilakukan pada 3 MST hingga 7 MST. Pengendalian hama penyakit dilakukan dengan aplikasi pestisida dengan bahan aktif azoksistrobin $\left(200 \mathrm{~g}^{\mathrm{L}-1}\right)$ dan difenokonazol (125 g $\mathrm{L}^{-1}$ ) dengan dosis $0.5 \mathrm{ml} \mathrm{ha}^{-1}$ pada 9 MST. Pemanenan padi dilakukan pada 13 MST. Pengamatan dilakukan sebagai berikut:

Pengamatan pada pertumbuhan vegetatif $(3-7$ MST):

- Tinggi tanaman, diukur dari pangkal batang hingga ujung daun tertinggi

- Jumlah anakan, dihitung semua anakan yang daunnya telah terbuka penuh

- Warna daun, diukur menggunakan Bagan Warna Daun (BWD) pada daun yang telah membuka

Pengamatan destruktif (8 MST):

- Bobot biomassa (bobot basah dan kering tajuk dan akar)

- Volume akar

- Panjang akar
Pengamatan panen:

- Komponen hasil (jumlah anakan produktif, jumlah malai per rumpun, panjang malai, jumlah bulir per malai dan bobot per 1000 butir).

- Hasil: bobot ubinan $(2.5 \mathrm{~m} \times 2.5 \mathrm{~m})$ dan potensi hasil per ha (GKP dan GKG)

Analisis tanah berupa:

- C-organik, N, P, dan $\mathrm{K}$ tersedia dalam tanah serta $\mathrm{pH}$ tanah.

- Analisis jaringan pada jerami dan gabah saat panen.

- Populasi mikroba (Azotobacter, Azospirillum, Thiobacillus, dan bakteri pelarut P) total dalam tanah

Hasil analisis tanah dan mikroba dianalisis dengan uji t. Data pertumbuhan dan produksi dianalisis dengan uji $\mathrm{F}$ dan bila nyata dilanjutkan dengan uji Dunnet pada taraf uji 5\%.

\section{HASIL DAN PEMBAHASAN}

\section{Analisis Kandungan Hara Tanah}

Berdasarkan analisis tanah awal, lahan sawah penelitian mempunyai $\mathrm{pH} 6.3$ - 6.7, sedangkan kandungan C-organik yang terdapat dalam tanah sebesar $0.81-0.94 \%$. Kandungan N total sebanyak $0.07-0.1 \%$. Kandungan $\mathrm{P}$ tersedia dalam tanah sebesar $3.5-6.3 \mathrm{ppm}$ dan $\mathrm{K}_{2} \mathrm{O}$ sebesar $0.84-1.10$ me $100 \mathrm{~g}^{-1}$.

Hasil analisis yang disajikan pada Tabel 1 menunjukkan $\mathrm{pH}$ tanah meningkat, perlakuan satu dosis NPK yang ditambahkan jerami menunjukkan peningkatan $\mathrm{pH}$ terendah.

Tabel 1. Kandungan $\mathrm{pH}$ dan C-organik tanah

\begin{tabular}{|c|c|c|c|c|}
\hline \multirow{2}{*}{ Perlakuan } & \multicolumn{2}{|c|}{$\mathrm{pH}$} & \multicolumn{2}{|c|}{ C-organik (\%) } \\
\hline & S1 & $\mathrm{S} 2$ & S1 & $\mathrm{S} 2$ \\
\hline Jerami + 0.5 Dosis NPK & 6.3 & 7.0 & 0.92 & 0.55 \\
\hline Jerami + 0.5 Dosis NPK + POG + POC & 6.4 & 7.2 & 0.88 & 0.39 \\
\hline Jerami + 0.5 Dosis NPK + POG & 6.5 & 7.1 & 0.82 & 0.56 \\
\hline Jerami + 0.5 Dosis NPK + POG + PH 1 & 6.5 & 7.1 & 0.93 & 0.60 \\
\hline Jerami + 0.75 Dosis NPK + PH 2 & 6.6 & 7.2 & 0.86 & 0.47 \\
\hline Jerami +0.5 Dosis NPK + pukan & 6.6 & 7.1 & 0.81 & 0.43 \\
\hline Jerami + 0.5 Dosis NPK + PH 1 & 6.5 & 7.4 & 0.94 & 0.51 \\
\hline Jerami + 0,5 Dosis NPK + PH 2 & 6.7 & 7.2 & 0.90 & 0.47 \\
\hline Jerami + 1 Dosis NPK & 6.6 & 6.9 & 0.85 & 0.49 \\
\hline Tanpa Jerami + 1 Dosis NPK & 6.5 & 7.0 & 0.90 & 0.49 \\
\hline Jerami + 0.5 Dosis NPK + PH 3 & 6.5 & 7.4 & 0.87 & 0.38 \\
\hline Tanpa Jerami + 0.5 Dosis NPK + PH 3 & 6.6 & 7.2 & 0.89 & 0.34 \\
\hline Tanpa pupuk & 6.6 & 7.0 & 0.83 & 0.47 \\
\hline t-test & \multicolumn{2}{|c|}{$12.02 *$} & \multicolumn{2}{|c|}{$17.05 *$} \\
\hline$P$ value & \multicolumn{2}{|c|}{0.000} & \multicolumn{2}{|c|}{0.000} \\
\hline
\end{tabular}

Keterangan : S1 : sebelum perlakuan ; S2 : setelah perlakuan ; *: berbeda nyata terhadap uji t pada taraf 5\% 
Hasil analisis kandungan C-organik dalam tanah setelah perlakuan menunjukkan terjadinya penurunan pada semua perlakuan. Penurunan C-organik tertinggi terjadi pada perlakuan setengah dosis NPK dengan jerami yang ditambahkan $\mathrm{PH} 3$ sebesar $0.55 \%$ terhadap kondisi awal. Penurunan kandunga C-organik tersebut diduga digunakan oleh tanaman untuk memenuhi kebutuhan nutrisinya.

Berdasarkan hasil analisis tanah yang disajikan pada Tabel 2, kandungan $\mathrm{N}$ dalam tanah meningkat setelah perlakuan. Penambahan jerami diduga mampu meningkatkan kandungan $\mathrm{N}$ dalam tanah. Hal ini sesuai dengan penelitian Indriyati (2006) bahwa jerami di dalam tanah dapat meningkatkan aktivitas enzim nitrogenase pada kondisi tergenang.

Adanya nitrogen sangat berpengaruh terhadap pembentukan senyawa karbon. Penambahan sisa-sisa tanaman (biomassa) dapat digunakan sebagai sumber $\mathrm{C}$ bagi tanah untuk memacu perkembangan populasi bakteri penambat N. Menurut Simanungkalit dan Suriadikarta (2006), dan Zuberer (1978) bahwa ketersediaan C-organik di lingkungan rhizosfer merupakan faktor utama yang menentukan banyaknya nitrogen yang dihasilkan.Berdasarkan hasil analisis pada Tabel 3, ketersediaan unsur hara $\mathrm{P}$ cenderung meningkat.
Tabel 2. Kandungan $\mathrm{N}$ total tanah sebelum dan setelah perlakuan

\begin{tabular}{lcc}
\hline \multirow{2}{*}{ Perlakuan } & \multicolumn{2}{c}{ N-Total (\%) } \\
\cline { 2 - 3 } & $\begin{array}{c}\text { Sebelu } \\
\mathrm{m}\end{array}$ & $\begin{array}{c}\text { Setela } \\
\mathrm{h}\end{array}$ \\
\hline Jerami + 0.5 Dosis NPK & 0.10 & 0.18 \\
Jerami + 0.5 Dosis NPK + POG + & & \\
POC & 0.08 & 0.16 \\
Jerami + 0.5 Dosis NPK + POG & 0.07 & 0.17 \\
Jerami + 0.5 Dosis NPK + POG + & & \\
PH 1 & 0.10 & 0.18 \\
Jerami + 0.75 Dosis NPK + PH 2 & 0.09 & 0.17 \\
Jerami + 0.5 Dosis NPK + pukan & 0.08 & 0.16 \\
Jerami + 0.5 Dosis NPK + PH 1 & 0.10 & 0.14 \\
Jerami + 0,5 Dosis NPK + PH 2 & 0.08 & 0.20 \\
Jerami + 1 Dosis NPK & 0.08 & 0.20 \\
Tanpa Jerami + 1 Dosis NPK & 0.09 & 0.19 \\
Jerami + 0.5 Dosis NPK + PH 3 & 0.09 & 0.15 \\
Tanpa Jerami + 0.5 Dosis NPK + & \multicolumn{2}{c}{} \\
PH 3 & 0.09 & 0.14 \\
Tanpa pupuk & 0.08 & 0.09 \\
t-test & \multicolumn{2}{c}{$-8.85 *$} \\
P val & \multicolumn{2}{c}{0.000} \\
\hline Keterangan : *: berbeda nyata terhadap uji t pada taraf 5\%
\end{tabular}

Aplikasi setengah dosis pupuk NPK dengan penambahan jerami dapat meningkatkan ketersediaan hara $\mathrm{P}$ yang tidak berbeda dengan penggunaan satu dosis pupuk NPK. Hal tersebut menunjukkan bahwa jerami dapat menyumbangkan $\mathrm{P}$ yang cukup besar.

Tabel 3. Kandungan $\mathrm{P}$ tersedia dan $\mathrm{K}_{2} \mathrm{O}$ total tanah sebelum dan setelah perlakuan

\begin{tabular}{|c|c|c|c|c|}
\hline \multirow{2}{*}{ Perlakuan } & \multicolumn{2}{|c|}{$P$ tersedia $(\mathrm{ppm})$} & \multicolumn{2}{|c|}{$\mathrm{K}_{2} \mathrm{O}$ total $(\mathrm{mg} / 100 \mathrm{~g})$} \\
\hline & S1 & $\mathrm{S} 2$ & S1 & $\bar{S} 2$ \\
\hline Jerami + 0.5 Dosis NPK & 3.5 & 7.28 & 0.84 & 7.57 \\
\hline Jerami + 0.5 Dosis NPK + POG + POC & 4.7 & 5.76 & 0.85 & 10.32 \\
\hline Jerami + 0.5 Dosis NPK + POG & 4.2 & 8.32 & 0.87 & 12.39 \\
\hline Jerami + 0.5 Dosis NPK + POG + PH 1 & 5.7 & 10.86 & 0.90 & 10.15 \\
\hline Jerami + 0.75 Dosis NPK + PH 2 & 4.9 & 8.12 & 0.96 & 8.81 \\
\hline Jerami + 0.5 Dosis NPK + pukan & 5.2 & 6.21 & 0.96 & 10.26 \\
\hline Jerami + 0.5 Dosis NPK + PH 1 & 6.0 & 4.67 & 1.02 & 7.77 \\
\hline Jerami + 0,5 Dosis NPK + PH 2 & 5.6 & 9.25 & 1.00 & 8.35 \\
\hline Jerami + 1 Dosis NPK & 5.4 & 18.10 & 1.06 & 12.21 \\
\hline Tanpa Jerami + 1 Dosis NPK & 5.7 & 13.85 & 1.08 & 10.93 \\
\hline Jerami + 0.5 Dosis NPK + PH 3 & 5.9 & 10.16 & 0.88 & 11.29 \\
\hline Tanpa Jerami + 0.5 Dosis NPK + PH 3 & 6.3 & 7.58 & 0.90 & 6.92 \\
\hline Tanpa pupuk & 5.5 & 2.30 & 1.10 & 0.68 \\
\hline t-test & \multicolumn{2}{|c|}{$-1.53^{\text {th }}$} & \multicolumn{2}{|c|}{$-4.29 *$} \\
\hline P val & \multicolumn{2}{|c|}{0.135} & \multicolumn{2}{|c|}{0.000} \\
\hline
\end{tabular}

Keterangan : *: nyata, tn: tidak nyata terhadap uji t pada taraf $5 \%$, S1: Sebelum perlakuan, S2 : Setelah perlakuan

Kandungan $\mathrm{K}_{2} \mathrm{O}$ total dalam tanah meningkat setelah perlakuan. Peningkatan tertinggi terdapat pada perlakuan jerami yang dengan setengah dosis NPK yang ditambahkan POG dan perlakuan jerami dengan satu dosis NPK. Perlakuan satu dosis pupuk NPK tanpa jerami menunjukkan peningkatan $\mathrm{K}$ yang lebih kecil dibandingkan dengan penambahan jerami pada satu dosiss NPK. Hal tersebut menunjukkan bahwa penambahan jerami penting untuk sumber $\mathrm{K}$ bagi tanaman padi sawah. 
Tabel 4. Serapan unsur hara pada jerami tanaman padi setelah perlakuan

\begin{tabular}{|c|c|c|c|c|}
\hline Perlakuan & $\begin{array}{c}\text { C-organik } \\
(\%)\end{array}$ & $\begin{array}{c}\text { N-Total } \\
(\%)\end{array}$ & $\begin{array}{c}\text { P Total } \\
(\%)\end{array}$ & $\begin{array}{c}\text { K Total } \\
(\%)\end{array}$ \\
\hline Jerami + 0.5 Dosis NPK & 46.2 & 0.8 & 0.1 & 1.2 \\
\hline Jerami + 0.5 Dosis NPK + POG + POC & 45.5 & 1.0 & 0.1 & 1.4 \\
\hline Jerami + 0.5 Dosis NPK + POG & 45.2 & 0.9 & 0.1 & 1.4 \\
\hline Jerami + 0.5 Dosis NPK + POG + PH 1 & 45.6 & 1.0 & 0.1 & 1.4 \\
\hline Jerami + 0.75 Dosis NPK + PH 2 & 44.4 & 1.0 & 0.1 & 1.4 \\
\hline Jerami +0.5 Dosis NPK + pukan & 45.0 & 1.0 & 0.1 & 1.5 \\
\hline Jerami + 0.5 Dosis NPK + PH 1 & 44.4 & 0.9 & 0.1 & 1.4 \\
\hline Jerami + 0,5 Dosis NPK + PH 2 & 44.3 & 0.9 & 0.1 & 1.5 \\
\hline Jerami + 1 Dosis NPK & 43.4 & 0.9 & 0.1 & 1.6 \\
\hline Tanpa Jerami + 1 Dosis NPK & 43.4 & 1.1 & 0.1 & 1.5 \\
\hline Jerami + 0.5 Dosis NPK + PH 3 & 43.2 & 1.0 & 0.1 & 1.6 \\
\hline Tanpa Jerami + 0.5 Dosis NPK + PH 3 & 44.5 & 1.0 & 0.1 & 1.6 \\
\hline Tanpa pupuk & 44.2 & 1.0 & 0.1 & 1.7 \\
\hline
\end{tabular}

Berdasarkan hasil analisis yang disajikan pada Tabel 4, kandungan C-organik dalam jerami berkisar antara 43.21\% - 46.15\%. Hasil pengamatan Dobermann and Fairhurst (2000) menunjukkan bahwa serapan $\mathrm{N}$ pada jerami $0.6 \%$ $0.8 \%$, serapan $\mathrm{P} 0.08 \%-0.12 \%$, dan serapan $\mathrm{K}$ sebesar $1.2 \%-1.7 \%$ pada jerami varietas modern di Asia. Serapan $\mathrm{N}$ etalah perlakuan tergolong tinggi $(0.8 \%-1 \%)$. Serapan P dalam jerami sama pada masing-masing perlakuan $(0.1 \%)$ tergolong sedang. Serapan K dalam jerami setelah perlakuan tergolong sedang. Serapan K pada jerami lebih tinggi dibandingkan serapan $\mathrm{N}$ dan $\mathrm{P}$.

Tabel 5. Serapan unsur hara pada gabah padi setelah perlakuan

\begin{tabular}{|c|c|c|c|c|}
\hline Perlakuan & $\begin{array}{c}\text { C-organik } \\
(\%)\end{array}$ & $\begin{array}{c}\text { N-Total } \\
(\%)\end{array}$ & $\begin{array}{c}\text { P Total } \\
(\%)\end{array}$ & $\begin{array}{c}\text { K Total } \\
(\%)\end{array}$ \\
\hline Jerami + 0.5 Dosis NPK & 52.3 & 1.1 & 0.3 & 0.9 \\
\hline Jerami + 0.5 Dosis NPK + POG + POC & 52.3 & 1.2 & 0.3 & 0.9 \\
\hline Jerami +0.5 Dosis NPK + POG & 53.5 & 1.2 & 0.3 & 0.9 \\
\hline Jerami + 0.5 Dosis NPK + POG + PH 1 & 54.0 & 1.6 & 0.4 & 0.8 \\
\hline Jerami + 0.75 Dosis NPK + PH 2 & 53.3 & 1.5 & 0.3 & 0.9 \\
\hline Jerami + 0.5 Dosis NPK + pukan & 54.1 & 1.7 & 0.4 & 0.9 \\
\hline Jerami + 0.5 Dosis NPK + PH 1 & 54.2 & 1.7 & 0.4 & 1.0 \\
\hline Jerami + 0,5 Dosis NPK + PH 2 & 53.7 & 1.3 & 0.3 & 1.0 \\
\hline Jerami + 1 Dosis NPK & 54.2 & 1.4 & 0.3 & 1.0 \\
\hline Tanpa Jerami + 1 Dosis NPK & 53.7 & 1.6 & 0.3 & 1.0 \\
\hline Jerami + 0.5 Dosis NPK + PH 3 & 53.7 & 1.5 & 0.3 & 1.2 \\
\hline Tanpa Jerami + 0.5 Dosis NPK + PH 3 & 54.2 & 1.6 & 0.3 & 1.2 \\
\hline Tanpa pupuk & 53.7 & 1.3 & 0.3 & 1.2 \\
\hline
\end{tabular}

Berdasarkan hasil analisis yang disajikan pada Tabel 5, kandungan C-organik dalam gabah berkisar antara $52.3 \%-54.2 \%$. Hasil pengamatan Dobermann and Fairhurst (2000) menunjukkan bahwa serapan $\mathrm{N}$ pada gabah $0.9 \%-1.2 \%$, serapan $\mathrm{P} 0.17 \%-0.23 \%$, dan serapan $\mathrm{K}$ sebesar $0.2 \%-0.3 \%$ pada gabah varietas modern di Asia. Serapan $\mathrm{N}$ dalam gabah lebih tinggi dibandingkan serapan $\mathrm{P}$ dan K pada gabah. Serapan N tergolong tinggi kecuali pada perlakuan jerami dan setengah dosis NPK maupun yang tidak ditambahkan POG dan POC. Serapan P dan K pada gabah tergolong tinggi.

Berdasarkan hasil unsur hara yang terangkut pada Tabel 6, kandungan C-organik berkisar antara $8.6 \mathrm{~g}$ per rumpun dimana kandungan terendah terdapat pada perlakuan tanpa pupuk. Unsur hara $\mathrm{N}$ yang terangkut jerami berkisar antara 0.22-0.29 g per rumpun. Unsur hara $\mathrm{P}$ yang terangkut jerami berkisar antara 0.2$0.3 \mathrm{~g}$ per rumpun. Unsur hara $\mathrm{K}$ yang terangkut jerami berkisar antara 0.32-0.44 $\mathrm{g}$ per rumpun. 
Tabel 6. Unsur hara terangkut oleh jerami padi (g per rumpun)

\begin{tabular}{lcccc}
\hline Perlakuan & C-organik & $\mathrm{N}$ & $\mathrm{P}$ & $\mathrm{K}$ \\
\hline Jerami + 0.5 Dosis NPK & 12.72 & 0.22 & 0.02 & 0.34 \\
Jerami + 0.5 Dosis NPK + POG + POC & 12.94 & 0.29 & 0.03 & 0.39 \\
Jerami + 0.5 Dosis NPK + POG & 12.22 & 0.24 & 0.03 & 0.38 \\
Jerami + 0.5 Dosis NPK + POG + PH 1 & 10.97 & 0.25 & 0.03 & 0.34 \\
Jerami + 0.75 Dosis NPK + PH 2 & 10.76 & 0.24 & 0.03 & 0.34 \\
Jerami + 0.5 Dosis NPK + pukan & 11.65 & 0.25 & 0.03 & 0.38 \\
Jerami + 0.5 Dosis NPK + PH 1 & 10.92 & 0.22 & 0.02 & 0.35 \\
Jerami + 0,5 Dosis NPK + PH 2 & 12.99 & 0.26 & 0.03 & 0.44 \\
Jerami + 1 Dosis NPK & 10.46 & 0.23 & 0.02 & 0.39 \\
Tanpa Jerami + 1 Dosis NPK & 10.34 & 0.26 & 0.03 & 0.35 \\
Jerami + 0.5 Dosis NPK + PH 3 & 11.29 & 0.25 & 0.03 & 0.43 \\
Tanpa Jerami + 0.5 Dosis NPK + PH 3 & 9.28 & 0.20 & 0.02 & 0.34 \\
Tanpa pupuk & 8.60 & 0.20 & 0.02 & 0.32 \\
\hline
\end{tabular}

Berdasarkan Tabel 7, unsur hara Corganik yang terangkut tanaman pada bagian gabah berkisar antara $22.01-26.37 \mathrm{~g}$ per rumpun. Perlakuan P13 menunjukkan unsur C-organik terangkut terendah (pada gabah maupun jerami).
Unsur hara $\mathrm{N}$ yang terangkut gabah berkisar antara $0.53-0.85 \mathrm{~g}$ per rumpun. Unsur hara $\mathrm{P}$ yang terangkut gabah berkisar antara 0.11-0.18 g per rumpun. Unsur hara $\mathrm{K}$ yang terangkut gabah berkisar antara 0.37-0.58 g per rumpun.

Tabel 7. Unsur hara terangkut oleh gabah (g per rumpun)

\begin{tabular}{lcccc}
\hline Perlakuan & C-organik & $\mathrm{N}$ & $\mathrm{P}$ & $\mathrm{K}$ \\
\hline Jerami + 0.5 Dosis NPK & 24.74 & 0.53 & 0.13 & 0.41 \\
Jerami + 0.5 Dosis NPK + POG + POC & 24.28 & 0.57 & 0.15 & 0.41 \\
Jerami + 0.5 Dosis NPK + POG & 25.91 & 0.56 & 0.14 & 0.45 \\
Jerami + 0.5 Dosis NPK + POG + PH 1 & 23.51 & 0.70 & 0.16 & 0.37 \\
Jerami + 0.75 Dosis NPK + PH 2 & 25.74 & 0.74 & 0.14 & 0.42 \\
Jerami + 0.5 Dosis NPK + pukan & 26.37 & 0.85 & 0.18 & 0.44 \\
Jerami + 0.5 Dosis NPK + PH 1 & 25.55 & 0.78 & 0.17 & 0.49 \\
Jerami + 0,5 Dosis NPK + PH 2 & 27.22 & 0.67 & 0.14 & 0.50 \\
Jerami + 1 Dosis NPK & 24.20 & 0.61 & 0.13 & 0.43 \\
Tanpa Jerami + 1 Dosis NPK & 26.13 & 0.76 & 0.15 & 0.50 \\
Jerami + 0.5 Dosis NPK + PH 3 & 25.66 & 0.71 & 0.15 & 0.58 \\
Tanpa Jerami + 0.5 Dosis NPK + PH 3 & 23.64 & 0.70 & 0.13 & 0.54 \\
Tanpa pupuk & 22.01 & 0.54 & 0.11 & 0.48 \\
\hline
\end{tabular}

Analisis ketersediaan hara dilakukan menggunakan pendekatan model QUEFTS (Dobermann and Fairhurst, 2000). Berdasarkan
Tabel 8, ketersediaan hara menunjukkan status terbatas, optimum, berlebihan dan sangat berlebihan pada unsur $\mathrm{N}, \mathrm{P}$, dan $\mathrm{K}$.

Tabel 8. Analisis ketersediaan haratanah berdasarkan serapan hara tanaman ( $\left.\mathrm{kg} \mathrm{ton}^{-1} \mathrm{gabah}\right)$

\begin{tabular}{|c|c|c|c|c|c|c|}
\hline Perlakuan & $\mathrm{N}$ & $\mathrm{s}$ & $\mathrm{P}$ & $\mathrm{s}$ & $\mathrm{K}$ & S \\
\hline Jerami + 0.5 Dosis NPK & 11 & $\mathrm{~T}$ & 2.7 & $\mathrm{O}$ & 21 & $\mathrm{~B}$ \\
\hline Jerami + 0.5 Dosis NPK + POG + POC & 12 & $\mathrm{~T}$ & 3.2 & B & 22.6 & B \\
\hline Jerami + 0.5 Dosis NPK + POG & 12 & $\mathrm{~T}$ & 2.9 & B & 23.4 & $\mathrm{~B}$ \\
\hline Jerami + 0.5 Dosis NPK + POG + PH 1 & 16 & $\mathrm{O}$ & 3.6 & B & 22.7 & $\mathrm{~B}$ \\
\hline Jerami + 0.75 Dosis NPK + PH 2 & 15 & $\mathrm{O}$ & 3.0 & B & 22.9 & B \\
\hline Jerami + 0.5 Dosis NPK + pukan & 17 & B & 3.6 & B & 23.7 & B \\
\hline Jerami + 0.5 Dosis NPK + PH 1 & 17 & B & 3.5 & B & 24.8 & B \\
\hline Jerami + 0,5 Dosis NPK + PH 2 & 13 & $\mathrm{~T}$ & 2.8 & $\mathrm{O}$ & 24.7 & B \\
\hline Jerami + 1 Dosis NPK & 14 & $\mathrm{O}$ & 3.0 & B & 25.8 & B \\
\hline Tanpa Jerami + 1 Dosis NPK & 16 & $\mathrm{O}$ & 3.1 & B & 25.0 & B \\
\hline Jerami + 0.5 Dosis NPK + PH 3 & 15 & $\mathrm{O}$ & 3.1 & B & 28.5 & SB \\
\hline Tanpa Jerami + 0.5 Dosis NPK + PH 3 & 16 & $\mathrm{O}$ & 3.0 & B & 28.8 & SB \\
\hline Tanpa pupuk & 13 & $\mathrm{~T}$ & 2.8 & $\mathrm{O}$ & 28.5 & SB \\
\hline
\end{tabular}

Keterangan : s: status, ST: sangat terbatas, T : terbatas, o: optimum, B: berlebihan, SB: sangat berlebihan 
Ketersediaan $\mathrm{N}$ berada pada status terbatas hingga berlebih, perlakuan jerami dengan setengah dosis NPK yang ditambahkan pukan atau PH1 mempunyai status $\mathrm{N}$ yang berlebih. Ketersediaan P berada pada status optimum atau berlebih, sedangkan ketersediaan $\mathrm{K}$ berada pada status berlebih atau sangat berlebih.

\section{Analisis Mikroba}

Salah satu mikroba atau bakteri yang penting dalam membantu ketersediaan nutrisi tanaman adalah bakteri penambat nitrogen seperti

Tabel 9. Analisis mikroba pada beberapa perlakuan

\begin{tabular}{|c|c|c|c|c|}
\hline \multirow[t]{2}{*}{ Perlakuan } & \multicolumn{2}{|c|}{$\begin{array}{c}\text { Azospirillum sp. (MPN/g) } \\
\text { x } 10^{4}\end{array}$} & \multicolumn{2}{|c|}{$\begin{array}{c}\text { Azotobacter sp. (CFU/g) } \\
\text { x } 10^{4} \\
\end{array}$} \\
\hline & $\mathrm{S} 1$ & S2 & S1 & $\mathrm{S} 2$ \\
\hline Jerami + 0.5 Dosis NPK & 35 & $* \operatorname{ttd}$ & 2.45 & 120 \\
\hline Jerami + 0.5 Dosis NPK + POG + POC & 15 & 0.21 & 2.70 & 3200 \\
\hline Jerami + 0.5 Dosis NPK + POG & 40 & 7.50 & 3.35 & 1800 \\
\hline Jerami + 0.5 Dosis NPK + POG + PH 1 & 20 & 9.30 & 3.65 & 4500 \\
\hline Jerami + 0.75 Dosis NPK + PH 2 & 55 & 0.75 & 2.00 & 21 \\
\hline Jerami + 0.5 Dosis NPK + pukan & 40 & 0.75 & 3.60 & 5100 \\
\hline Jerami + 0.5 Dosis NPK + PH 1 & 30 & 0.36 & 2.80 & 33 \\
\hline Jerami + 0,5 Dosis NPK + PH 2 & 15 & 230 & 2.60 & 120 \\
\hline Jerami + 1 Dosis NPK & 50 & 0.36 & 3.15 & 490 \\
\hline Tanpa Jerami + 1 Dosis NPK & 45 & 1.50 & 3.60 & 2200 \\
\hline Jerami + 0.5 Dosis NPK + PH 3 & 12 & 29.0 & 3.80 & 65 \\
\hline Tanpa Jerami + 0.5 Dosis NPK + PH 3 & 20 & 0.36 & 3.55 & 470 \\
\hline Tanpa pupuk & 30 & 0.74 & 3.50 & 48 \\
\hline T-Test & \multicolumn{2}{|c|}{0.54} & \multicolumn{2}{|c|}{$-2.76^{*}$} \\
\hline $\mathrm{P}$ value & \multicolumn{2}{|c|}{0.598} & \multicolumn{2}{|c|}{0.017} \\
\hline
\end{tabular}

Azospirillum sp. dan Azotobacter sp. Berdasarkan hasil analisis mikroba yang disajikan pada Tabel 9, bakteri Azospirillum cenderung menurun, kecuali pada perlakuan setengah dosis NPK dengan jerami yang ditambahkan PH1 atau PH3. Penurunan jumlah populasi tersebut diduga karena $\mathrm{pH}$ tanah (netral) kurang sesuai dengan $\mathrm{pH}$ optimum Azospirillum (asam) dan kondisi anaerob pada tanah sawah sehingga bakteri tersebut kurang berkembang. Akan tetapi, berdasarkan uji t populasi Azospirillum berbeda nyata antara sebelum dan setelah perlakuan.

Keterangan : S1 : sebelum, S2 : setelah perlakuan, *ttd : tidak terdeteksi, *: nyata, tn: tidak nyata terhadap uji t pada taraf 5\%

Populasi bakteri Azotobacter meningkat jumlah populasinya dan berbeda nyata setelah perlakuan. Perlakuan jerami dengan setengah dosis NPK yang ditambahkan dengan pukan menunjukkan jumlah populasi tertinggi. Hal ini terjadi karena kondisi $\mathrm{pH}$ tanah yang sesuai dengan $\mathrm{pH}$ optimum pertumbuhan Azotobacter. Bakteri Azotobacter mampu tumbuh optimum dan dapat memfiksasi nitrogen pada pH 7 - 7,5 (Holt et al., 1994). Selain itu, bakteri ini juga dapat tumbuh pada kondisi keterbatasan oksigen (anaerobik). Bakteri Azotobacter mampu menfiksasi nitrogen tanpa harus berasosiasi dengan tanaman (Marschner, 1995).

Berdasarkan hasil analisis pada Tabel 10, populasi bakteri Thiobacillus cenderung meningkat kecuali pada perlakuan jerami yang ditambahkan satu dosis NPK atau setengah dosis NPK dengan PH3. Bakteri ini tidak terdeteksi pada perlakuan jerami dengan setengah dosis NPK dengan penambahan POG atau PH2. Hal ini diduga karena $\mathrm{pH}$ tanah yang tidak sesuai (netral) dengan $\mathrm{pH}$ optimum Thiobacillus ( $\mathrm{pH} 1.3$ - 4.5).
Selain itu, Thiobacillus yang bersifat aerobik sehingga kurang berkembang pada lumpur sawah. Populasi bakteri Thiobacillus tidak berbeda nyata antara sebelum dan setelah perlakuan berdasarkan uji t yang dilakukan.

Meskipun bakteri Thiobacillus kurang berkembang di lahan sawah, tetapi masih ada bakteri pelarut fosfat lainnya. Bakteri tersebut mampu memineralisasi bahan organik dari senyawa fosfat organik menjadi fosfat anorganik sehingga dapat tersedia di tanah. Secara biologis bakteri tersebut memanfaatkan enzim fosfatase untuk mengubah bahan organik agar nutrisi dapat langsung diserap tanaman (Simanungkalit dan Suriadikarta, 2006).

Populasi ketersediaan bakteri pelarut $\mathrm{P}$ tertinggi terdapat pada perlakuan jerami dengan setengah dosis NPK yang ditambahkan POG dan PH1. Hal ini diduga karena penggunaan jerami dengan setengah dosis NPK yang ditambahkan POG dan PH1 mampu menyediakan nutrisi bagi bakteri untuk hidup dan beraktivitas dalam tanah. 
Tabel 10. Analisis mikroba pada beberapa perlakuan

\begin{tabular}{|c|c|c|c|}
\hline \multirow[t]{2}{*}{ Perlakuan } & \multicolumn{2}{|c|}{$\begin{array}{l}\text { Thiobacillus sp. } \\
(\mathrm{CFU} / \mathrm{g}) \times 10^{4}\end{array}$} & \multirow{2}{*}{$\begin{array}{c}\text { Bakteri pel. fosfa } \\
(\mathrm{CFU} / \mathrm{g})\end{array}$} \\
\hline & S1 & $\mathrm{S} 2$ & \\
\hline Jerami + 0.5 Dosis NPK & 3.00 & 4.8 & $2.6 \times 10^{5}$ \\
\hline Jerami + 0.5 Dosis NPK + POG + POC & 3.45 & 6.5 & $3.1 \times 10^{6}$ \\
\hline Jerami + 0.5 Dosis NPK + POG & 2.15 & $* \mathrm{ttd}$ & $4.3 \times 10^{5}$ \\
\hline Jerami +0.5 Dosis NPK + POG + PH 1 & 2.00 & 2.9 & $9.1 \times 10^{7}$ \\
\hline Jerami + 0.75 Dosis NPK + PH 2 & 2.60 & 9.1 & $2.9 \times 10^{6}$ \\
\hline Jerami +0.5 Dosis NPK + pukan & 1.35 & 2.2 & $3.1 \times 10^{6}$ \\
\hline Jerami + 0.5 Dosis NPK + PH 1 & 1.40 & 5.1 & $4.0 \times 10^{5}$ \\
\hline Jerami + 0,5 Dosis NPK + PH 2 & 3.45 & $* \mathrm{ttd}$ & $3.0 \times 10^{5}$ \\
\hline Jerami + 1 Dosis NPK & 2.80 & 1.9 & $5.2 \times 10^{7}$ \\
\hline Tanpa Jerami + 1 Dosis NPK & 2.10 & 7.7 & $4.1 \times 10^{7}$ \\
\hline Jerami + 0.5 Dosis NPK + PH 3 & 7.05 & 1.9 & $* \mathrm{ttd}$ \\
\hline Tanpa Jerami + 0.5 Dosis NPK + PH 3 & 4.90 & 6.4 & $2.4 \times 10^{5}$ \\
\hline Tanpa pupuk & 2.90 & 4.3 & $6.7 \times 10^{5}$ \\
\hline T-test & \multicolumn{2}{|c|}{$-1.14^{\mathrm{tn}}$} & \\
\hline$P$ value & \multicolumn{2}{|c|}{0.269} & \\
\hline
\end{tabular}

Keterangan : S1 : sebelum, S2 : setelah perlakuan, *ttd : tidak terdeteksi, *: nyata, tn: tidak nyata terhadap uji t pada taraf 5\%

Selain itu, perlakuan satu dosis NPK dengan atau tanpa jerami juga dapat menyediakan bakteri pelarut fosfat terbesar. Hal ini diduga bahwa nutrisi yang diperlukan bakteri pelarut fosfat untuk hidup dapat dicukupi oleh satu dosis pupuk NPK, baik dengan jerami maupun tanpa jerami.

\section{Pertumbuhan dan Produksi}

Aplikasi pembenaman jerami dan pupuk hayati atau pupuk organik dengan reduksi pupuk NPK tidak berpengaruh terhadap pertumbuhan tinggi tanaman pada 3, 5, dan 7 MST. Perlakuan juga tidak menunjukkan berbeda nyata terhadap panjang akar, volume akar, bobot basah dan kering biomassa.serta komponen hasil tanaman.

\section{Jumlah Anakan}

Aplikasi pembenaman jerami dan pupuk hayati atau pupuk organik dengan reduksi pupuk NPK tidak berpengaruh terhadap jumlah anakan pada 3 dan 5 MST.

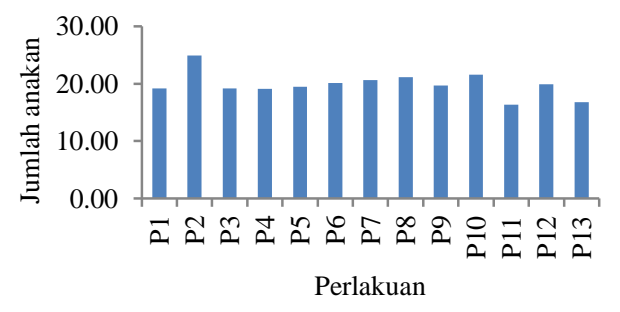

Gambar 1. Jumlah anakan pada 7 MST
Akan tetapi pada 7 MST setelah perlakuan, terlihat pengaruh yang sangat nyata pada jumlah anakannya.

Perlakuan jerami dengan setengah dosis NPK yang ditambahkan POG dan POC pada 7 MST menunjukkan jumlah anakan tertinggi, sedangkan jumlah anakan terendah terdapat pada perlakuan jerami dengan setengah dosis NPK yang ditambahkan PH3. Berdasarkan hal tersebut terlihat bahwa penambahan POC dan POG mampu meningkatkan jumlah anakan dibanding tanpa pemberian dua unsur tersebut.

\section{Bagan Warna Daun}

Bagan warna daun merupakan alat indikator kecukupan nitrogen pada padi. Berdasarkan uji Dunnet yang dibandingkan dengan perlakuan satu dosis NPK tanpa penambahan jerami, perlakuan tidak berbeda nyata pada 5 dan 7 MST, sedangkan pada 3 MST perlakuan tanpa pupuk menunjukkan berbeda nyata terhadap perlakuan pembanding. Perlakuan tanpa pupuk dan jerami menunjukkan skor warna daun terendah. Hal ini menunjukkan kecukupan nitrogen pada tanaman yang rendah.

Warna daun pada perlakuan tanpa pupuk menunjukkan skor 2.97 pada 7 MST. Hal tersebut menandakan bahwa kecukupan hara $\mathrm{N}$ pada tanaman rendah. Berdasarkan hasil pengamatan, pada perlakuan tidak terdapat warna daun yang menunjukkan skor 4, yang berarti bahwa tanaman tidak memerlukan nitrogen tambahan. 
Tabel 11. Warna daun pada beberapa perlakuan pemupukan

\begin{tabular}{lccc}
\hline \multicolumn{1}{c}{ Perlakuan } & \multicolumn{3}{c}{ Umur Tanaman (MST) } \\
\cline { 2 - 4 } & 3 & 5 & 7 \\
\hline Jerami + 0.5 Dosis NPK & 2.87 & 3.03 & 3.30 \\
Jerami + 0.5 Dosis NPK + POG + POC & 3.00 & 3.27 & 3.57 \\
Jerami + 0.5 Dosis NPK + POG & 2.67 & 3.17 & 3.10 \\
Jerami + 0.5 Dosis NPK + POG + PH 1 & 2.70 & 3.10 & 3.17 \\
Jerami + 0.75 Dosis NPK + PH 2 & 2.87 & 3.23 & 3.23 \\
Jerami + 0.5 Dosis NPK + pukan & 2.87 & 3.27 & 3.30 \\
Jerami + 0.5 Dosis NPK + PH 1 & 2.80 & 3.17 & 3.20 \\
Jerami + 0,5 Dosis NPK + PH 2 & 2.60 & 3.23 & 3.23 \\
Jerami + 1 Dosis NPK & 2.53 & 3.23 & 3.43 \\
Tanpa Jerami + 1 Dosis NPK & 2.93 & 3.23 & 3.37 \\
Jerami + 0.5 Dosis NPK + PH 3 & 2.53 & 3.07 & 3.23 \\
Tanpa Jerami + 0.5 Dosis NPK + PH 3 & 2.87 & 3.00 & 3.03 \\
Tanpa pupuk & $2.13^{* *}$ & $3.03^{\text {tn }}$ & $2.97^{\text {tn }}$ \\
\hline
\end{tabular}

Keterangan : **: nyata, tn : tidak nyata terhadap uji Dunnet pada taraf 5\%

Berdasarkan analisis ragam, perlakuan tidak berpengaruh nyata terhadap hasil ubinan baik bobot basah maupun kering. Perlakuan setengah dosis NPK dengan pembenaman jerami dan ditambahkan PH2 mampu menghasilkan ratarata bobot kering ubinan, GKP, dan GKG tertinggi, sedangkan perlakuan tanpa pupuk

Tabel 12. Bobot ubinan dan dugaan hasil menunjukkan hasil terendahnya. Rendahnya hasil produksi pada perlakuan tanpa pupuk menunjukkan bahwa ketersediaan hara bagi tanaman rendah. Hal ini juga telah ditunjukkan pada skor BWD paling rendah pada perlakuan tersebut.

\begin{tabular}{lccrr}
\hline \multirow{2}{*}{$\quad$ Perlakuan } & \multicolumn{2}{c}{ Ubinan } & Pg) & \multicolumn{2}{c}{ Potensi Hasil ha $^{-1}$ (ton) } \\
\cline { 2 - 5 } & BB & BK & \multicolumn{1}{c}{ GKP } & GKG \\
\hline Jerami + 0.5 Dosis NPK & 5.87 & 5.30 & 9.40 & 8.48 \\
Jerami + 0.5 Dosis NPK + POG + POC & 5.82 & 5.20 & 9.31 & 8.32 \\
Jerami + 0.5 Dosis NPK + POG & 5.92 & 5.43 & 9.47 & 8.68 \\
Jerami + 0.5 Dosis NPK + POG + PH 1 & 5.63 & 4.88 & 9.00 & 7.80 \\
Jerami + 0.75 Dosis NPK + PH 2 & 6.34 & 5.41 & 10.14 & 8.66 \\
Jerami + 0.5 Dosis NPK + pukan & 6.16 & 5.46 & 9.86 & 8.74 \\
Jerami + 0.5 Dosis NPK + PH 1 & 5.77 & 5.28 & 9.24 & 8.45 \\
Jerami + 0,5 Dosis NPK + PH 2 & 6.33 & 5.68 & 10.13 & 9.08 \\
Jerami + 1 Dosis NPK & 5.79 & 5.01 & 9.27 & 8.01 \\
Tanpa Jerami + 1 Dosis NPK & 6.03 & 5.46 & 9.65 & 8.73 \\
Jerami + 0.5 Dosis NPK + PH 3 & 6.00 & 5.35 & 9.60 & 8.56 \\
Tanpa Jerami + 0.5 Dosis NPK + PH 3 & 5.49 & 4.88 & 8.78 & 7.81 \\
Tanpa pupuk & 5.39 & 4.59 & 8.63 & 7.34 \\
\hline
\end{tabular}

Berdasarkan potensi hasil yang dicapai terhadap GKG setelah perlakuan, setiap perlakuan cenderung dapat menghasilkan produksi padi hingga mencapai potensi hasil (GKG) padi varietas Ciherang $\left(8\right.$ ton $\left.\mathrm{ha}^{-1}\right)$. Perlakuan jerami pada setengah dosis NPK dengan penambahan POG, POC, pukan, maupun $\mathrm{PH}$ dapat menghasilkan GKG yang tidak berbeda nyata dengan produksi padi satu dosis NPK. Hal ini menunjukkan bahwa ketersediaan hara pada setengah dosis NPK dengan penambahan POG, POC, pukan, maupun $\mathrm{PH}$ dapat mencukupi kebutuhan tanaman dan mampu menghasilkan produksi yang tidak berbeda dengan penggunaan satu dosis NPK.
Peningkatan hasil yang dibandingkan dengan perlakuan satu dosis NPK tanpa penambahan jerami, perlakuan setengah dosis NPK yang ditambahkan jerami dan PH2 dapat meningkatkan hasil $4.05 \%$ lebih besar dibandingkan perlakuan satu dosis NPK tanpa penambahan jerami. Perlakuan setengah dosis NPK dengan penambahan jerami dan pukan juga dapat meningkatkan hasil $0.10 \%$ lebih besar dibandingkan pembanding. 
Tabel 13. Peningkatan hasil produksi dibandingkan perlakuan satu dosis NPK tanpa jerami

\begin{tabular}{lc}
\hline \multicolumn{1}{c}{ Perlakuan } & $\begin{array}{c}\text { Peningkatan } \\
\text { Hasil }(\%)\end{array}$ \\
\hline Jerami + 0.5 Dosis NPK & -2.80 \\
Jerami + 0.5 Dosis NPK + POG + POC & -4.68 \\
Jerami + 0.5 Dosis NPK + POG & -0.51 \\
Jerami + 0.5 Dosis NPK + POG + PH 1 & -10.59 \\
Jerami + 0.75 Dosis NPK + PH 2 & -0.81 \\
Jerami + 0.5 Dosis NPK + pukan & 0.10 \\
Jerami + 0.5 Dosis NPK + PH 1 & -3.16 \\
Jerami + 0,5 Dosis NPK + PH 2 & 4.05 \\
Jerami + 1 Dosis NPK & -8.25 \\
Tanpa Jerami + 1 Dosis NPK & 0.00 \\
Jerami + 0.5 Dosis NPK + PH 3 & -1.99 \\
Tanpa Jerami + 0.5 Dosis NPK + PH 3 & -10.51 \\
Tanpa pupuk & -15.89 \\
\hline
\end{tabular}

\section{KESIMPULAN}

Pembenaman jerami dan penambahan Pupuk Hayati (baik PH1, PH2, maupun PH3) atau pupuk organik dapat meningkatkan ketersediaan hara dan populasi mikroba tanah. Aplikasi pembanaman jerami dan pupuk hayati serta pupuk organik dengan reduksi setengah dosis pupuk NPK mampu meningkatkan pertumbuhan tanaman khususnya jumlah anakan dan bagan warna daun. Produksi padi yang dihasilkan tidak berbeda nyata antar perlakuan. Perlakuan setengah dosis NPK yang ditambahkan jerami dan PH2 dapat meningkatkan potensi hasil $4.05 \%$ lebih tinggi daripada perlakuan satu dosis NPK tanpa penambahan jerami.

\section{DAFTAR PUSTAKA}

Cho, Y. S., Kobata. 2002. N top-dressing and rice jerami application for low input cultivation of transplanted rice in Japan. Korean J. Crop Sci. 47(4):273-278.

Dobermann, A., Fairhurst, T. 2000. Rice Nutrient Disorders and Nutrient Management. Potash and Phosphate Institute of Canada and International Rice Research Institute. Canada: Oxford Geographic Printers Pte Ltd.

Dwiyanto. 2008. Revolusi Hijau [Internet]. [diunduh 2010 Sep 27]. Tersedia pada: http:///E:/penelitian/27sept10/discuss.biof ertilizerp.htm.
Hamim, Nisa, R., Ida, H.S., Nani, S. 2007. Pengaruh pupuk biologi terhadap pola serapan hara, ketahanan penyakit, produksi dan kualitas hasil beberapa komoditi tanaman pangan dan sayuran unggulan [laporan penelitian]. Bogor (ID): Institut Pertanian Bogor.

Havlin, J.L., Beaton, J.D., Tisdale, S.L., Nelson, W.L. 2005. Soil Fertility and Fertilizer, An Introduction to Nutrient Management $7^{\text {th }}$. Upper saddle River : Pearson Prentice Hall.

Holt, J.G., Krieg, N.R., Sneath, P.H.A., Staley, J.T., William, S.T. 1994. Bergey's Manual of Determinative Bacteriology. Ninth Ed. Philadelphia: Lippincot Williams and Wilkins.

Indriyati, L.T. 2006. Transformasi nitrogen dalam tanah tergenang : aplikasi jerami padi dan urea serta hubungannya dengan serapan nitrogen dan pertumbuhan tanaman padi [disertasi]. Bogor (ID): Institut Pertanian Bogor.

Marschner, H. 1995. Mineral Nutrition of Higher Plants. San Diego : Academic Press Inc.

Simanungkalit, Suriadikarta, D.A. 2006. Pupuk organik dan pupuk hayati (organic fertilizer and biofertilizereditor). Di dalam: Simanungkalit, R.D.M., Suriadikarta, D. A., Saraswati, R., Setyorini, D., Hartatik, W., editors. Peranan Pupuk Organik dan Pupuk Hayati dalam Keberlanjutan Produksi dan Kelestarian Lingkungan. Jawa Barat (ID): Balai Besar Litbang Sumberdaya Lahan Pertanian Badan Penelitian dan Pengembangan Pertanian. hlm 10-14.

Widya, Nasih. 2006. Pupuk Hayati [Internet]. [diunduh 2010 Sep 26]. Tersedia pada: http://nasih.staff.ugm.ac.id/p/008biofertili zer.htm.

Wolf, D.C., Wagner, G.H. 2005. Principle and apllication of soil microbiology $2^{\text {nd }}$. Di dalam: Silvia, D.M., Jeffry, J. F., Peter, G. H., David, A.Z., editors. Carbon Transformation and Soil Organic Matter Formation. Upper Saddle River, NewJersey: Pearson Education. p 285331. 